\title{
XXXIII Congresso Brasileiro de Oftalmologia
}

\author{
3 a 6 de Setembro de 2005 - Fortaleza - CE
}

“... Eu sou brasileiro, filho do Nordeste. Sou cabra da peste, sou do Ceará ..."

Patativa do Assaré

O Homem só pode ser compreendido inserido no seu contexto social, lendo-se social como incluindo o econômico, o histórico, o educativo.

Apraz-nos, pois localizar o nosso XXXIII Congresso Brasileiro de Oftalmologia no contexto histórico e social do Brasil, que por sua vez não pode abstrair o contexto mundial. Hoje, mais do que nunca, uma época de globalização.

Há 30 anos atrás, as facilidades de comunicação, de recursos econômicos e financeiros, de hospedagem, de disponibilidade dos participantes de congressos eram bem menores do que as da atualidade, orquestradas pelo transporte aéreo, os computadores, a Internet, os hotéis de luxo ou de classe turista, os Centros de Convenções e tantos meios de apoio imediato. Contudo, mesmo com as limitações da época, o XVIII Congresso Brasileiro de Oftalmologia foi realizado, em nossa cidade, com brilhantismo e destacado conteúdo científico.

Consideremos ainda o ambiente sócio-político do país. Há
30 anos vivíamos numa sociedade militarmente fechada e hoje, apesar da democratização operada pela atual Constituição da República, estamos tolidos por pessoas politicamente incorretas, pela deficiência de ética, fato constatado diariamente pelos meios de comunicação de massa.

Apesar dessa situação descrita com aspectos positivos e negativos, gostaríamos de poder levar a êxito nosso congresso - O XXXIII Congresso Brasileiro de Oftalmologia - e esperamos, com as bênçãos de Deus e a ajuda de todos os colegas, o êxito desejado.

Ao apresentar a programação científica do Congresso, cabe-nos agradecer a confiança em nós depositada pelo Presidente do Conselho Brasileiro de Oftalmologia - Dr. Elisabeto Ribeiro Gonçalves - para presidir o segundo maior evento mundial de Oftalmologia e ao Prof. Harley Bicas, editor-chefe dos Arquivos Brasileiros de Oftalmologia, pela oportunidade que nos ofereceu de escrever o presente editorial.

Prof. Dr. Leiria de Andrade Neto Presidente do XXXIII Congresso Brasileiro de Oftalmologia

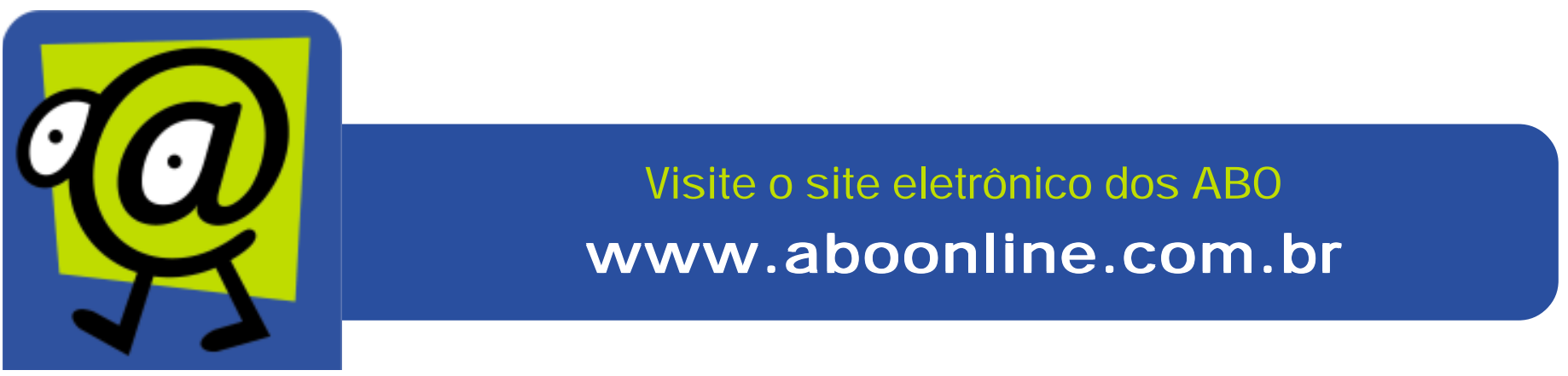

